\title{
Development of Management Control System Research: Study on Behavioral Research in Accounting Journal (2006-2018)
}

\author{
SeTin $^{1}$ \\ Yvonne Augustine ${ }^{2}$ \\ ${ }^{1}$ Faculty of Economics, Maranatha Christian University, Indonesia \\ ${ }^{2}$ Faculty of Bussiness, Trisakti University, Indonesia \\ email: setin2005@yahoo.com
}

DOI: https://doi.org/10.24843/JIAB.2020.v15.i01.p12

\begin{tabular}{l}
$\begin{array}{l}\text { Jurnal Ilmiah Akuntansi } \\
\text { dan Bisnis } \\
\text { (JIAB) }\end{array}$ \\
\hline Volume 15 \\
Issue 1 \\
January 2020 \\
Page 127 - 138S \\
p-ISSN 2302-514X \\
e-ISSN 2303-1018 \\
\hline ARTICLE INFORMATION: \\
\hline Received: \\
30 May 2019 \\
Revised: \\
11 October 2019 \\
Accepted: \\
28 November 2019 \\
\hline
\end{tabular}

\begin{abstract}
This paper provides a descriptive analysis of management control system (MCS) in BRIAjournal from 2006 to 2018. A total of 180 articles were examined, resulting in the identification of 34 articles for further analysis. The analysis led to several findings. Most of the articles use quantitative methods, examine MCS at the managerial level, and emphasize one-or two-dimensional control systems. The dominant topics are strategic performance measurement system, budget, reward compensation system, and performance achievement. The dominant independent variables are incentives, psychological, strategy performance measurement systems, and environmental dynamism. The dominant dependent variables are performance and psychological variables. Environmental dynamism and environmental uncertainty are the external contingencies that affect performance, and the most dominant internal contingency is the variable related to individual factors. Finally, the majority of the article use contingency variables that tend to concentrate on increasing the number of independent rather than dependent variables.
\end{abstract}

Keywords: Management control system, BRIA Journal 2006-2018.

\section{INTRODUCTION}

This paper was triggered by Otley (2016) who reviewed the literature on the contingency theory of management accounting especially the topic of management control system (MCS) since 1980 until 2014. Otley (2016) had searched articles from nine major accounting journals, namely Accounting, Organizations and Society, Management Accounting Research, British Accounting Review, Journal of Management Accounting Research, Accounting Auditing and Accountability Journal, European Accounting Review, Accounting and Business Research, The Accounting Review, and Journal of Accounting Research. Otley (2016) showed that the contingency approach has become one of the success stories of research in the field of management accounting specifically the management control system (MCS) for the last forty years. However, Otley (2016) underlined the major deficiency of 40 years of research is the lack of attention paid to the conceptualization of the overall MCS.
Behavioral Research in Accounting (BRIA) journal was not included in the journal examined by Otley. This is most likely because the journal BRIA was first published in 1989, while Otley (2016) began in 1980. This paper aims to broaden Otley (2016) by examining management accounting research developments in the area of MCS in the BRIA journal during the period 2006-2018. The purpose is to provide an overview of the development of management control system research.

It is very important for practitioners and researchers to know the development of MCS research in order to understand the role of MCS in complex, uncertain and ever-changing environments. The development of the MCS is very dependent on the results of the research conducted. Research findings provide a platform about the control system used by organizations and their impact on organizational outcomes. Therefore, knowing the development of MCS research is very important. 
Many management accounting researchers have argued about the issues of control with behavior in order to achieve goal congruence between individual goals and organizational goals. Some of them are Merchant \& Van der Stede (2007) separate management control from strategic control and define management control as dealing with employees' behavior. Abernethy \& Chua, (1996, p.573) employ the same line of argument in defining an organizational control system as comprising "a combination of control mechanisms designed and implemented by management to increase the probability that organizational actors will behave in ways consistent with the objectives of the dominant organizational coalition. Flamholtz et al. (1985, p.47) defined organizational controls as: "attempts by the organization to increase the probability that individuals and groups will behave in ways that lead to the attainment of organizational goals. Malmi \& Brown (2008) explain that control is about managers ensuring that the behavior of employees is consistent with the organization's objectives and strategy.

Based on the opinions, it can be concluded that who make things happen in the organization is the "people" in the organization. Management controls are necessary to guard against the possibilities that people will do something the organization does not want them to do or fail to do something they should do. Most likely, it is no need for MCS if all employees could always be relied on to do what is best for the organization. MCS is a techniques and processes to achieve goal congruence which may be designed for all levels of behavioral influence: individuals, small groups, formal subunits and the organization as a whole (Flamholtz et al., 1985). The close connection between control and behavior is in line with Lee (2001) which suggests that future accounting research should refer to behavior-related research.

Before BRIA was born in 1989, research in behavioral accounting was widely published in prestigious accounting journals, for example The Accounting Review; Journal of Accounting Research; and Accounting, Organizations \& Society. However, these journals did not focus on behavioral research.

With the continuous development of accounting research related to behavior, BRIA is here as a special journal that contains research in the behavioral area. The field of management accounting that is highly intersected with behavior proved to be quite dominating the number of articles since the beginning of BRIA's issuance up to today. Kusuma (2003) conducted BRIA study during 1989-1999 and the results showed that in the first five years of BRIA publication (1989-1993), there were 44 distributed writings with equal amount between ethics, auditing and management accounting (20\% each). In the next six years of BRIA publication (1994-1999). Of the 95 writings, the auditing portion reached $30 \%$ while the management accounting reached $28 \%$. MingKuang \& SeTin, (2010) continued BRIA's analysis of the period 1998-2003. The results showed that of the 43 most frequently published articles / topic articles are Accounting Information Processing (26\%), Auditing (37\%), and Managerial Control (16\%). SeTin et al. (2017) analyzed the development of BRIA for the period 2005-2014, the results showed that from a total of 121 articles, $16.52 \%$ were management accounting topics and became the most dominant topic.

Management accounting and management control are closely related. Both have long been seen as identical practical concepts (Otley, 1999). One of the benefits of management accounting is providing the basis for ongoing corporate control. Because of the close relationship between management accounting and management control, the BRIA journal as a journal dominated by management accounting articles becomes a very relevant journal to be chosen in analyzing the development of MCS.

BRIA's 2006-2018 journal search related to MCS research aims to enrich Otley (2016) which analyzed the development of MCS for 34 years in the major accounting journal. The purpose of this paper is to analyze management accounting research developments in the area of MCS for the last ten years (2006-2018) in BRIA Journal. Based on Otley (2016), this study answer the following questions: 1) What is the topic issues discussed in the MCS research? 2) What are the dominant research methods used and the unit of research analysis? 3) For MCS research using quantitative methods, what are the most common independent and dependent variables studied in MCS topics? 4) What are the contextual factors (contingency variables) that affect the relation between control systems and performance? 5) Do contingency variables work as independent variables, mediating or moderating 
variables? 6) How broad is the scope of control system dimension in MCS research?

Since the introduction in the 1970s, the contingency approach has become one of the central paradigms in management accounting research (Riyanto, 2003). The main issue of research is to identify factors that affect the effectiveness of control systems, by testing contextual factors that affect the relation between control system and performance. Budget participation research topics which used the contingency approach are Brownell, 1982; Govindarajan, 1986; Brownell \& Hirst, 1986; Kren, 1992. Contextual factors which were found will determine the effect of control systems on performance are motivation, commitment, organizational structure, environmental uncertainty and strategy, and other variables that are generally outside the accounting domain.

Therefore, research in the field of management control is always associated with various other fields of science. Although the empirical findings have already supported the concept of contingent management control, research findings are, in general, still partial in explaining the use of control systems for the company comprehensively including planning, monitoring, implementing, evaluating and reward systems (Riyanto, 2003). Then, how the development of contextual factors (contingency variables) in management control research last 10 years? It became one of the important questions that are analyzed in this paper.

Arnold \& Sutton (1997) criticized previous behavioral accounting research namely that there is excessive diversity in the measurement of operational variables, a lack of conceptual clarity of the constructs of variables, a disproportionate focus on methodology, and weak theory development. Future research requires a strong conceptual and theoretical foundation that integrates management psychology and literature to provide broad results in its application.

Lee (2001) suggested that future accounting research should: (1) refer to behavior-related researches, e.g about decision driven; (2) combining accounting research with other sciences; (3) focusing on something that has no solution. Management control topic opens great opportunities for the development of accounting researches which topics can follow Lee's advice (2001). In the field of management control, Riyanto (2003) classified the research agenda into three main parts, namely (1) Integration (testing the whole control system) of companies that can improve performance; (2) Extensions (expanding the literature by identifying control variables that have not been studied); (3) Improvement of research methods. Carenys (2012) suggested that future management control research will combine the use of formal systems with financial and non-financial indicators, with an informal system, to create a "control package". Sendjaja (2015) explained that the focus of management accountants has shifted to be more efficient, integrated, more predictive in estimating the development of organizations.

The shifting focus of management accountants is also due to the industrial revolution 4.0 that marked by the unification of smart technology has an impact on customer expectations, product quality and the company's operational model. This impact affects individual behavior and at the same time changes the way organizations do business (Ali, 2019) and presents major challenges related to concept control that can answer business problems.

The trends can also be the starting point of future management accounting research. With the shifting focus of management accounting, it needs a concept control that is able to integrate all the companyoriented value creation strategy for the company. The development of this research is highly anticipated for its contribution to business practices and to enrich the repertoire of research in the area of management accounting, especially in the field of control systems.

\section{RESEARCH METHOD}

This research used descriptive analysis to explain and describe the development of management control research in the area of management accounting in the thirteen years (2006 to 2018). The development of MCS research is traced by examining management control articles in the BRIA journal.

Descriptive analysis is done by answering the five questions begin with the word "what". After answering all the questions, this study synthesizes all the answers (making inferences) that summarize the development of management control system research. The analysis is done by: 1) Checking the issues of MCS topics referred to Anthony \& Govindarajan (2003). 2) Checking the category of 
methods and level of analysis used in each MCS studies. The method category referred to Otley (2016), namely empirical and using quantitative methods; theoretical; review, qualitative or methodological. Level of analysis in each study will check whether they are managerial level, company level or business unit; 3) Identifying the independent variables and the most common studied dependent variables; 4) Identifying the contextual factors (variables of contingencies) that affect the relation between control systems and performance. Whether contingent variables have an impact on organization's performance is a category of external contingency (internal uncertainty) or internal contingency (business strategy) (Burkert et al., 2014; Chenhall, 2003), or individual factors (Riyanto, 2003). The analysis also involved whether the contingency variable serves as a predictor / independent variable (Chenhall, 2003) or as a mediating or moderating variable (Burkert et al., 2014). 5) Checking whether the articles use the concept of MCS as a package (Malmi \& Brown, 2008) that comprehensively examines the control of the system as a whole or the article focuses only on one or more control system dimensions. The analysis also involved on how wide of the scope of the control system dimension, which involved aspects of planning, cybernetic controls, rewards and compensation, administrative controls and cultural controls (Malmi \& Brown, 2008).

\section{RESULTS AND DISCUSSION}

The research article topic of the MCS is searched with using electronic database which provide an access to the BRIA Journal. The time specified in the search filter spanned from 2006 to 2018 . The articles generated were reviewed by title and abstract. The MCS topic findings are shown in Table 1

Table 1. The MCS Topic Findings in BRIA 2006-2018

\begin{tabular}{ccccc}
\hline Year & $\begin{array}{c}\text { Total } \\
\text { Article }\end{array}$ & $\begin{array}{c}\text { MCS topic } \\
\text { In the field of } \\
\text { Management Accounting }\end{array}$ & $\begin{array}{l}\text { MCS topic } \\
\text { In the field of } \\
\text { Auditing }\end{array}$ & $\begin{array}{l}\text { Not } \\
\text { MCS topic }\end{array}$ \\
\hline 2006 & 13 & 2 & 3 & 8 \\
2007 & 13 & 2 & 0 & 11 \\
2008 & 14 & 3 & 2 & 9 \\
2009 & 11 & 3 & 1 & 7 \\
2010 & 13 & 4 & 1 & 8 \\
2011 & 20 & 1 & 0 & 19 \\
2012 & 17 & 5 & 2 & 10 \\
2013 & 14 & 4 & 0 & 11 \\
2014 & 13 & 1 & 1 & 11 \\
2015 & 14 & 2 & 5 & 8 \\
2016 & 12 & 3 & 2 & 8 \\
2017 & 13 & 3 & 4 & 124 \\
2018 & 13 & 1 & 22 & \\
\hline Total & 180 & 34 & & 1 \\
\hline
\end{tabular}

Source: Processed Data, 2019

Table 1. shows that the total number of articles reviewed are 180 articles. From 180 articles, found that some topics of MCS in two fields of accounting, namely the field of management accounting and auditing, as well as some other topics outside the MCS. The number of relevant studies on MCS topics was found to be $31 \%$ (56 of 180 articles) and as many as $69 \%$ (124 out of 180 articles) of irrelevant to MCS topic. Of the 56 MCS topic articles, 34 articles or $19 \%$ of the total articles reviewed (34 of 180 articles) are topics in management accounting and the remaining 22 articles are MCS topics in auditing. Table 1 also showed that the MCS topic, although not dominant in terms of number of articles, but always be present in every journal publication year. For auditing, MCS topic issues are related to auditor performance, audit quality, audit judgment, job outcomes, whistleblowing and audit efficiency and effectiveness. As for the topic of MCS in the field of management accounting will be described in table 2 below, and for the next analysis, this paper will focus on 34 articles MCS in the management accounting area. 
Table 2. Use of Methods in MCS Research Topic in The Management Accounting Area in BRIA 2006-2018

\begin{tabular}{|c|c|c|c|c|}
\hline \multirow[b]{2}{*}{ Year } & \multirow{2}{*}{$\begin{array}{l}\text { Total } \\
\text { Article }\end{array}$} & \multicolumn{2}{|c|}{ Quantitative Method } & \multirow[t]{2}{*}{$\begin{array}{c}\text { Review } \\
\text { Literature } \\
\end{array}$} \\
\hline & & Experiment Method & Survey Method & \\
\hline 2006 & 2 & 1 & 1 & \\
\hline 2007 & 2 & 1 & 1 & \\
\hline 2008 & 3 & 1 & 2 & \\
\hline 2009 & 3 & 2 & 1 & \\
\hline 2010 & 4 & 2 & 2 & \\
\hline 2011 & 1 & 1 & 0 & \\
\hline 2012 & 5 & 4 & 1 & \\
\hline 2013 & 4 & 2 & 2 & \\
\hline 2014 & 1 & 0 & 1 & \\
\hline 2015 & 2 & 1 & 1 & \\
\hline 2016 & 3 & 2 & 1 & \\
\hline 2017 & 3 & 1 & 1 & 1 \\
\hline 2018 & 1 & 1 & 0 & \\
\hline Total & 34 & 19 & 14 & 1 \\
\hline
\end{tabular}

Source: Processed Data, 2019

Table 2 shows that the total number of articles included in the bibliography are 34 articles. 33 articles used quantitative methods and 1 article used review literature. Of these 19 can be categorized using experiment methods and the remainder using empirical method with survey. Unlike Otley (2016), this analysis has found no use qualitative methods in MCS research.

Table 3. MCS Topics Issues in The Management Accounting Area in BRIA 2006-2018

\begin{tabular}{|c|c|c|c|c|c|c|c|c|}
\hline \multirow{2}{*}{$\begin{array}{l}\text { Total } \\
\text { Article }\end{array}$} & \multicolumn{3}{|c|}{ Budget } & \multirow{2}{*}{$\begin{array}{c}\text { Reward \& } \\
\text { Compensation } \\
\text { system }\end{array}$} & \multirow{2}{*}{$\begin{array}{c}\text { Strategic } \\
\text { Performance } \\
\text { Measurement } \\
\text { System }\end{array}$} & \multirow{2}{*}{$\begin{array}{l}\text { Performance } \\
\text { achievement }\end{array}$} & \multirow{2}{*}{$\begin{array}{l}\text { Controller } \\
\text { function }\end{array}$} & \multirow[b]{2}{*}{ Others } \\
\hline & Budget & $\begin{array}{c}\text { Capital } \\
\text { budgeting }\end{array}$ & $\begin{array}{l}\text { budgetary } \\
\text { slack }\end{array}$ & & & & & \\
\hline 2 & 1 & 0 & 0 & 0 & 1 & 0 & 0 & 0 \\
\hline 2 & 0 & 0 & 0 & 1 & 1 & 0 & 0 & 0 \\
\hline 3 & 0 & 1 & 0 & 0 & 2 & 0 & 0 & 0 \\
\hline 3 & 1 & 0 & 0 & 1 & 1 & 0 & 0 & 0 \\
\hline 4 & 1 & 0 & 2 & 1 & 0 & 0 & 0 & 0 \\
\hline 1 & 0 & 0 & 1 & 0 & 0 & 0 & 0 & 0 \\
\hline 5 & 0 & 0 & 0 & 0 & 2 & 3 & 0 & 0 \\
\hline 4 & 0 & 0 & 0 & 1 & 2 & 1 & 0 & 0 \\
\hline 1 & 0 & 0 & 0 & 0 & 1 & 0 & 0 & 0 \\
\hline 2 & 0 & 0 & 0 & 0 & 1 & 0 & 1 & 0 \\
\hline 3 & 0 & 0 & 0 & 1 & 0 & 0 & 0 & 2 \\
\hline 3 & 0 & 0 & 0 & 0 & 0 & 1 & 0 & 2 \\
\hline 1 & 0 & 0 & 0 & 0 & 0 & 0 & 0 & 1 \\
\hline 34 & 3 & 1 & 3 & 5 & 11 & 5 & 1 & 5 \\
\hline
\end{tabular}

Source: Processed Data, 2019

Table 3 showed that during the period 20062018, from the BRIA journal search results, the most dominant issue of MCS in management accounting is the strategic performance measurement system (SPMS), which is as many as 11 articles and budget issues including capital budgeting and budgetary slack (7 articles). Next, almost the same amount is filled by reward and compensation system issues ( 5 articles); performance achievement that includes task performance, performance improvements and performance target ( 5 articles). Just only one article for the controller function. Other topics related to levers of control and control disclosure. Some of the MCS topics presented by Anthony \& Govindarajan (2003) but not found in this study were responsibility centers, profit centers, transfer pricing, strategic planning, measuring and controlling employed assets. 
Table 4. Level of Analysis MCS Research Topic in BRIA 2006-2018

\begin{tabular}{|c|c|c|c|c|c|c|}
\hline Year & $\begin{array}{l}\text { Total } \\
\text { Article }\end{array}$ & $\begin{array}{c}\text { Staff level } \\
\text { (Non- } \\
\text { management) }\end{array}$ & $\begin{array}{l}\text { Managerial } \\
\text { level }\end{array}$ & $\begin{array}{l}\text { Organizational } \\
\text { Level }\end{array}$ & $\begin{array}{l}\text { Department } \\
\text { level }\end{array}$ & $\begin{array}{c}\text { Business } \\
\text { unit }\end{array}$ \\
\hline 2006 & 2 & & 1 & & 1 & \\
\hline 2007 & 2 & 1 & 1 & & & \\
\hline 2008 & 3 & & 2 & 1 & & \\
\hline 2009 & 3 & & 2 & & 1 & \\
\hline 2010 & 4 & 1 & 2 & & & 1 \\
\hline 2011 & 1 & & 1 & & & \\
\hline 2012 & 5 & 1 & 3 & & & 1 \\
\hline 2013 & 4 & 1 & 3 & & & \\
\hline 2014 & 1 & & & & & 1 \\
\hline 2015 & 2 & & 2 & & & \\
\hline 2016 & 3 & 2 & & 1 & & \\
\hline $\begin{array}{l}2017 \\
2018 \\
\end{array}$ & $\begin{array}{l}3 \\
1 \\
\end{array}$ & 2 & 1 & & & 1 \\
\hline Total & 34 & 8 & 18 & 2 & 2 & 4 \\
\hline
\end{tabular}

Source: Processed Data, 2019

Table 4 showed that the topic of MCS research in the 2006-2018 BRIA journal in management accounting was dominated by analysis at the managerial level, which was as many as 53\% (18 of 34 articles). The rest are non-management level analysis ( 8 articles), business units (4 articles), department level ( 2 articles) and organizational level (2 articles).

Independent variables that are commonly studied are variables related to incentives, psychological, strategy performance measurement systems and environmental dynamism. Variables related to incentives, such as incentive structure or incentive system, pay scheme and incentive intensity. Variables related to psychological, such as personal values, commitment, involvement and role in management, social pressure, Machiavellianism, management communication, obedience pressure, risk individual preference, enabling perception, influence manager, independencies, information asymmetry, time pressure, fault line conflict, argument framing (persuasive message). Variables related to performance measurement system (SPMS), such as financial measure, nonfinancial measure and their favorableness, performance measurement in diversity (in use), target and outcome for the performance measure, dominance treatment actual performance outcome. Variables related to environmental dynamism, such as market changes, technological changes, production technologies, knowledge of new product, service developments, innovation and empowerment, product standardization, firm strategy, quality in the manufacturing strategy, task uncertainty. Other independent variables that are also found are control weakness corrections, levers of control, organizational climate, organizational risk appetite. Some variables in budgeting settings (aggregation and timing of budgets), managerial likeability, managerial procedural safeguards, core financial need beliefs (financial competence and financial community).

The independent variables mentioned above, some of them also has been included in Otley, 2016 in his analysis of contingency theory of management accounting and control development 1980-2014. For variables related to environmental dynamism, incentives and psychological in this study, also has been found by Otley (2016) including variables technology, market competition, environmental uncertainty, compensation systems and psychological variables. What's interesting in the findings of the current study is that the variable of strategy performance measurement system is an independent variable that is classified as dominant but not the dominant in Otley, 2016. For example, the performance management system is linked to trust 
(Lau \& Scully, 2015); associated with behavioral work outcomes (Burney \& Widener, 2013); and tested the effect on managers 'and their superiors' expectations about the manager's effort (Cianci et al., 2013).

Likewise, the national culture, organizational size, structure is the most commonly examined independent variables in Otley, 2016, but nothing of those were found in this study. From the analysis of the last 3 years (2016-2018), this study found several psychological variables that were not found by Otley, 2016. For examples, fault line conflict is linked to incentives and individual effort (YuTian et al., 2016); argument framing (persuasive messages) is linked to employee attitude (Young, 2017); and disclosure control weakness is linked to trust (Rose et al., 2016). This difference of the findings with Otley (2016) also enriched the description of the development of MCS research, especially the issues that have been tested as independent variables.

In this study, the dependent variable that dominates is the performance that is as many as of $52 \%$ (14 of 27 articles). Performance variables include performance evaluation, performance judgment of ambiguity, performance improvements and performance measurement system failure, target specificity. Performance levels measured include department performance, managerial performance, non-management employee and group or team performance. Performance is also the most widely examined dependent variables in Otley (2016). However, there is a difference between the performance as an outcome variable that Otley had discovered, 2016 with the findings in the current study. In Otley (2016), performance is the major dependent variables used in financial performance being the most commonly used outcome variable. One of the major reasons is that financial performance is widely used in most organizations. Moreover, most variable compensation systems use a measure of financial performance as the indicator for incentives payments.

In the present study, the performance is more related to non-financial performance that includes several aspects of performance such as evaluation, judgment, improvements and measurements at various levels within the organization. The results of this study are also supported by Lau \& Scully (2015); Kaplan et al. (2012), which states that recent research on performance measurement systems has also focused increasingly on the use of nonfinancial measures as measures of organizational and employee performance. This finding certainly enriches Otley (2016) which shows that performance is more related to financial performance than nonfinancial performance. Because after all, the overreliance of performance measures on financial performance may produce biased results.

Besides the performance variables, the other dependent variables found in this study are psychological related variables, which are as many as $53 \%$ (18 of 34 articles), which include stress response, trust, individual behavior, participation in budgeting, moral judgment regarding budgetary slack, slack creation, hedonic utility, reporting intentions to the manager related fraud, belief, empowerment and creativity. The findings of psychological variables as dependent variables become very interesting because these psychological variables are hardly found in Otley (2016). Even in the last 3 years of BRIA publishing, all dependent variables related to control system were psychological variables. This may be due to BRIA as the only sample of this study that specifically contains behavioral articles (behavioral aspects) in the field of accounting. Other than those are as many as $5.9 \%$ ( 2 of 34 articles) are variable capital budgeting and use of information sources. Several dependent variables which are found many in Otley (2016) but those that are not found in this study are MCS design and its use, effectiveness, change in practices and product innovation.

Thus, it can be concluded that, the dependent variable in the MCS research found in BRIA for the last 13 years is able to give a color which will enrich the description of the development of MCS research issues, especially those related to psychological aspects and broader aspects of performance.

Table 5 showed that the number of MCS articles which used the contingency variables found in the BRIA journal 2006-2018 are as many as 38\% (13 of 34 articles). As comparison, this paper provides Otley (2016) analysis of the number of control management research articles that used the contingency variables during 1980-2014 period that is as many as 236 articles, with the details of the journal and the number of articles as follows: Accounting, Organization and Society (66 articles); Management Accounting Research (57 articles); British Accounting Review 
(22 articles); Journal of Management Accounting Research (13 articles); Accounting, Auditing and Accountability Journal (9); European Accounting Review (9); Accounting and Business Research (7); Information and Management (4); Strategic Management Control (4); Administrative Science Quarterly (3); Journal of Management (3).

Referring to Otley (2016) that conducted an analysis of 11 journals published for 34 years, it can be concluded that the number of MCS articles that used the contingency variables found in the BRIA 2006-2018 journal is quite a lot. Contextual factors (contingency variables) in MCS research, especially the research that examines the relation between control system and performance can be categorized as external contingency, internal contingency (Burkert et al., 2014; Chenhall, 2003) and individual factor (Riyanto, 2003). Contingency variables can serve as predictor / independent variables (Chenhall, 2003; Tsamenyi et al., 2011) or as mediating and moderating variables (Burkert et al., 2014).

A number of contingency variables was found in this study. Contingency variables which are external contingency categories that has an impact on performance are environmental dynamism and environmental uncertainty (volatility, complexity, strategic, task uncertainty). While contingency variables which are internal contingency categories that has an impact on performance are variables as follow (1) individual factors, such as self-efficacy; psychological contract; intensity of use, psychological empowerment, motivation, commitment, attitude, role conflict, role ambiguity, managerial experience, negativity treatment conditions, team cognitive orientation (2) incentive intensity; (3) performance measurement diversity (in use); (4) job relevant information; (5) the evaluative process.

Contingency variables found in this study, some of which serve as predictor / independent variable, which is environmental dynamism, task uncertainty, incentive intensity, negativity treatment conditions. Contingency variables that act as mediating variables are self-efficacy, psychological contract, intensity of use, psychological empowerment, role conflict, motivation, job relevant information; Role ambiguity. While Contingency variables that serve as moderating variable are team cognitive orientation, complexity, performance measurement diversity (in use), the evaluative process, complexity, managerial experience.

From the above results it can be seen that most of the MCS research that used contingency variables tend to concentrate on increasing the number of independent variables rather than on the dependent variables. This is showed by the contingency variables mentioned above which are all related to performance as a dependent variable. This result supports Otley (2016). The study now shows only one article that uses contingency variables that are not related to performance but capital budgeting methods as the dependent variable. Contingency variables used are product standardization and firm strategy.

Of all the variables used in the original studies of the contingency theory of organizational structure, the one that has gained by far the widest attention in the area of management accounting is that of environmental uncertainty (Otley, 2016). This seems to be for several reasons. First, if an organization or unit is faced by high levels of uncertainty it requires flexible and adaptable systems to manage activities when unexpected events occur. Second, environmental uncertainty has increased over the years, in part due to the emergence of the global economy and more extensive competition. It also caused by organization ceasing to attempt to control all aspects of the value chain within one overall (holding) organization and the relative demise of the divisionalised organization.

In this study, two articles that used external contingency were found, namely Buchheit et al. (2012) and Dekker et al. (2012). Buchheit et al. (2012) examined environmental uncertainty, which include volatility, complexity and strategic relation related to outcome feedback and incentive towards performance improvements. The result suggested that financial incentives and outcome feedback are both critical to performance improvement in relatively environmental uncertainty. Dekker et al. (2012) examined the relation between environmental dynamism with target specificity. Environmental dynamism includes market changes, technological changes, production technologies, knowledge new product, services developments. The result shows that both target specificity and the use of information sources to determine target levels vary with firms' environmental dynamism and task uncertainty, and 
with the intensity of financial incentives provided to subordinate managers

In this study, contingency variables are dominated by individual factors, such as selfefficacy; Psychological contract; Intensity of use, psychological empowerment, motivation, commitment, attitude, role conflict, role ambiguity, managerial experience, negativity treatment conditions, team cognitive orientation.

Some examples of studies that studied individual factors, namely Buchheit et al. (2012) examined individual factors such as motivation, commitment and attitude related to the relation between outcome feedback and incentive towards performance improvements. The result suggested that financial incentives and outcome feedback are both critical to performance improvement in relatively individual factors. Naranjo-Gil et al. (2012) examined team cognitive orientation as moderating variable between incentive systems and team performance. The result showed that enhanced team performance is positively related to both individual economic incentives and predominately collectivist orientation in the team, and that the effectiveness of any incentive system design seems to be related to the team's predominant cognitive orientation. Burney \& Widener (2013) found evidence that the extent to which an SPMS is tightly coupled with strategy affects employee performance through perceived self-efficacy and perceived psychological contract. Drake et al. (2007) suggested that feedback and rewards affect the dimensions of empowerment differently for lower-level workers than that who works for managers. Motivation was not significantly related to two of the three empowerment dimensions. Implications of this study are that techniques that work to increase manager perceptions of empowerment may not work at lower organizational levels and, even if successful, the related increase in employee motivation may not be significant.

For contingency variables related to internal contingency (strategy) and operation design factor (organizational culture and organizational structure) are hardly found in this study. However, the contingency variable in the form of individual factors dominates the research of MCS research published in the BRIA journal for the last ten years. With these findings, once again, it adds the horizons of the development of MCS research issues, especially those that used the contingency variable (individual factor) in examining the relation between control systems and performance.

Table 5. Control Section That Became The Research Area in BRIA 2006-2018

\begin{tabular}{|c|c|c|c|c|c|c|}
\hline \multirow[t]{2}{*}{ Year } & \multirow[t]{2}{*}{ Article } & \multicolumn{5}{|c|}{ MCS as a package } \\
\hline & & $\begin{array}{l}\text { Planning } \\
\text { Control }\end{array}$ & $\begin{array}{l}\text { Cybernetic } \\
\text { Control }\end{array}$ & $\begin{array}{l}\text { Reward \& } \\
\text { Compensation }\end{array}$ & $\begin{array}{l}\text { Administrative } \\
\text { Control }\end{array}$ & $\begin{array}{l}\text { Cultural } \\
\text { Control }\end{array}$ \\
\hline 2006 & 2 & * & $*$ & & $*$ & \\
\hline 2007 & 2 & $*$ & $*$ & 1 & & \\
\hline 2008 & 3 & * & 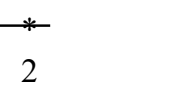 & & & \\
\hline 2009 & 3 & & 2 & 1 & & \\
\hline 2010 & 4 & & 3 & 1 & & \\
\hline 2011 & 1 & & 1 & & & \\
\hline 2012 & 5 & & 2 & 2 & 1 & \\
\hline 2013 & 4 & & $\begin{array}{l}2 \\
* \\
\end{array}$ & $\begin{array}{l}1 \\
* \\
\end{array}$ & & \\
\hline 2014 & 1 & & 1 & & & \\
\hline 2015 & 2 & & 1 & & 1 & \\
\hline 2016 & 3 & & 1 & & $\begin{array}{l}1 \\
2\end{array}$ & 1 \\
\hline 2017 & 3 & * & * & & $*$ & * \\
\hline 2018 & 1 & & & & 1 & \\
\hline$\sum$ & 34 & & 15 & 6 & 6 & 1 \\
\hline
\end{tabular}

Source: Processed Data, 2019 
Table 5. explained the extent of the control aspects discussed in the topic of MCS research in the BRIA journal during 2006-2018. The analysis referred to the wide range of control system dimensions including planning, cybernetic controls, rewards and compensation control, administrative controls and cultural controls (Malmi \& Brown, 2008).

Table 6. showed that only one article that examined the overall dimensions of the control system. The study is Speklé et al. (2017) that links control with creativity. There are 5 articles that discussed the relation between two dimensions of control, namely cybernetic control and administration control ( 1 article), planning control and cybernetic control ( 3 articles), and cybernetic control and reward control ( 1 article). The remaining 28 articles discussed one dimension of control. The dimensions of cybernetic control dominate the MCS topic as many as 15 articles. Cybernetic control related to hybrid measurement system ( 8 articles). Cybernetic control related to budget ( 5 articles), cybernetic control related to nonfinancial measurement system ( 2 articles), the rest are reward and compensation control ( 6 articles), administrative control (6 articles) consisting of organizational design and structure (1 article) and administrative control related to policies and procedures ( 4 articles). Table 6 also showed that the control dimensions that were not found in the topic research of MCS in BRIA journal 2006-2018 are administrative control related to governance structure and planning control related to action planning.

\section{CONCLUSION}

In general, the findings of this study are consistent with Otley'S findings, namely that the contingency approach also dominates the research of MCS, and this study also found the lack of attention paid to the conceptualization of the overall MCS. Similar to Otley (2016), this study found the use of various independent variables as contingency variables that are linked to performance. However, there are differences in the independent variable and the dependent variable that is dominantly used. Contingency variables in the form of individual factors and psychological variables as the dependent variable are the dominant variables found in this study and vice versa are very rarely found in Otley (2016). in other accounting fields such as finance, taxation, accounting information systems, ethics, and also related to new issues of corporate social responsibility in terms of sustainability and control. The topic of MCS opens great opportunities for the development of research in various fields of accounting as Lee (2001) advised on upcoming accounting research that should refer to behavioral research, which combines with other sciences and focuses on something that has not yet been resolved.

Only one article used literature review and no qualitative methods in research MCS are found, this provides opportunities for future research to utilize these methods to respond to the development of entities and shifting of focus of management accounting. Sendjaja (2015) explained that the focus of management accountants shifted to be more efficient, integrated, and more predictive in estimating the development of organizations. With this shifting, comprehensive control testing that can integrate corporate strategy in creating value is required. The use of varied research methods is recommended for future MCS research to enrich the MCS literature.

The study of MCS at the company level is still limited, so the MCS research in the future is suggested to define performance as the performance of the organization as measured by using the secondary data approach (data related to the financial aspect). This secondary data approach also reduces the frequent used survey disadvantages for collecting data, since dependent variables and independent variables are collected from two different sources (Riyanto, 2003).

The results showed that most of the MCS studies that used contingency variables tend to concentrate on increasing the number of independent variables rather than on the dependent variables (mostly related to performance). These results provide an upcoming research agenda for expanding contingency model control systems including the identification of variables that have not been or have been rarely studied, both dependent and independent variables. For example, variables related to operation design factor (organizational culture and organizational structure). Study that examined cultural variables (Chow et al., 1991) considered at the influence of national culture, not organizational culture. Studies on the effect of organizational culture are not much done yet. Fisher (1995) explained that organizational 
What is interesting in the findings of this study is that the strategy performance measurement system variable is an independent variable that counts as dominant but is not found as the dominant variable in Otley (2016). Likewise, the national culture, organizational size, structure was the most commonly examined independent variables in Otley, 2016, but not found in this study. Also for the dependent variable, in Otley (2016), performance was the major dependent variables used with financial performance being the most commonly used outcome variable. However, the performance found in the present study is more related to non-financial performance that includes several performance aspects such as evaluation, judgment, improvements and measurements at various levels within the organization. This finding certainly enriches Otley (2016) which showed that performance is more related to financial performance than non-financial performance. Because after all, the over-reliance of performance measures on financial performance may produce biased results.

The findings of psychological variables as dominant dependent variables become very interesting because these psychological variables are hardly found in Otley (2016). This may be due to BRIA as the only sample of this study that specifically contains behavioral articles (behavioral aspects) in the field of accounting. Likewise, some of the dependent variables found in Otley analysis, 2016 but those that are not found in this study are MCS design and its use, effectiveness, change in practices and product innovation. The difference of this findings with Otley (2016) enriches the development of MCS research, especially issues that are examined as independent variables and dependent variables related to psychological aspects and broader aspects of performance.

Contingency variable in the form of individual factor dominates the research of MCS published in BRIA journal for the last ten years. With these findings, once again, it adds the horizons of the development of MCS research issues, especially those that used the contingency variable (individual factor) in testing the relation between control systems and performance.

The absence of MCS topics in accounting other than management and auditing accounting provides great opportunities in the future for MCS research culture implies a set of social norms, values and beliefs that are shared by the members of the organization and their influence actions. He argued that a strong internal culture can decrease the need for other control mechanisms, and may thus affect the overall design of an MCS. This is therefore an important field to be studied in the future.

The research that had been conducted mostly focused on one dimension or several dimensions of the control system, and research that examined the effect of control systems on the overall control dimension found only one article. Otley, 2016 explained that although many elements of an overall MCS have been studied, these have been seen in isolation from the context of the other elements which surround them. Therefore testing of MCS as a package should be a concern in future research. This agenda is also urgently required considering the idea of a 'package' of control systems has been in existence since at least 1980 but has only recently begun to be taken seriously. This is proven by Otley (2016) analysis of 9 major accounting journals (total 11 journals) in 34 years, and the results showed that there was a lack of attention paid to the conceptualization of the overall MCS.

These research agendas are urged to enrich the repertoire of research in the MCS area, or more broadly in various fields of accounting. This paper has not conducted the empirical results of MCS research, and this can be a future research.

Overall, the results of this study are important as a basis for future studies to established theoretical propositions, and provides platform to fill many gaps in the topic of MCS. For practical implications, this study provides a comprehensive picture of how management control practices have been analyzed in the academic area so that practitioners in the business field can understand and determine appropriate controls to gain the utmost benefits for their business.

\section{REFERENCES}

Abernethy, M. A., \& Chua, W. F. (1996). A Field Study of Control System "Redesign": The Impact of Institutional Processes on Strategic Choice. Contemporary Accounting Research, 13(2), 569-607. https://doi.org/10.1111/j.19113846.1996.tb00515.x 
Ali, S. (2019). Revolusi Industri 4.0 dan Dampaknya terhadap Pendidikan Akuntansi di Indonesia (1st ed.). BPFE: Yogyakarta.

Anthony, R. N., \& Govindarajan, V. (2003). Management Control System (Elevent Ed). Mc GrawHill International Edition.

Arnold, V., \& Sutton, S. G. (1997). Behavioral Accounting Research/: Foundations and Frontiers. American Accounting Association, Sarasota, Fl.

Brownell, P. (1982). The Role of Accounting Data in Performance Evaluation, Budgetary Participation, and Organizational Effectiveness. Journal of Accounting Research, 20(1), 12. https://doi.org/10.2307/2490760

Brownell, P., \& Hirst, M. (1986). Reliance on Accounting Information, Budgetary Participation , and Task Uncertainty: Tests of a Three-Way Interaction Authors ( $\mathrm{s}$ ): Peter Brownell and Mark Hirst Published by: Wiley on behalf of Accounting Research Center, Booth School of Business, U. Journal of Accounting Research, 24(2), 241-249. https://doi.org/10.2307/2491132

Buchheit, S., Dalton, D., Downen, T., \& Pippin, S. (2012). Outcome Feedback, Incentives, and Performance: Evidence from A Relatively Complex Forecasting Task. Behavioral Research in Accounting, 24(2), 1-20. https:// doi.org/10.2308/bria-50151

Burkert, M., Davila, A., Mehta, K., \& Oyon, D. (2014). Relating Alternative Forms of Contingency Fit to The Appropriate Methods to Test Them. Management Accounting Research, 25(1), 6-29. https://doi.org/10.1016/ j.mar.2013.07.008

Burney, L. L., \& Widener, S. K. (2013). Behavioral Work Outcomes of A Strategic Performance Measurement System-Based Incentive Plan. Behavioral Research in Accounting, 25(2), 115-143. https://doi.org/https://doi.org/10.2308/ bria-50501

Carenys, J. (2012). Management Control Systems: A Historical Perspective. International Joural of Economy, Management and Social Sciences, 1(1), 1-18. https://www. researchgate.net/publication/293221830 Management_Control_Systems_A_ Historical_Perspective
Chenhall, R. H. (2003). Management Control Systems Design Within Its Organizational Context: Findings from Contingency-Based Research and Directions for The Future. Accounting, Organizations and Society, 28(2), 127-168. https://doi.org/10.1016/s03613682(01)00027-7

Chow, C. W., Shields, M. D., \& Chan, Y. K. (1991). The Effects of Management Controls and National Culture on Manufacturing Performance: An Experimental Investigation. Accounting Organizations and Society, 16(3), 209-226. https://doi.org/10.1016/03613682(91)90001-U

Cianci, A. M., Kaplan, S. E., \& Samuels, J. A. (2013). The Moderating Effects of The Incentive System and Performance Measure on Managers' and Their Superiors' Expectations about The Manager's Effort. Behavioral Research in Accounting, 25(1), 115-134. https:/ /doi.org/10.2308/bria-50290

Dekker, H. C., Groot, T., \& Schoute, M. (2012). Determining Performance Targets. Behavioral Research in Accounting, 24(2), 21-46. https:/ /doi.org/10.2308/bria-50097

Drake, A. R., Wong, J., \& Salter, S. B. (2007). Performance: Examining the Impact of. Behavioral Research in Accounting, 19, 7189. https://doi.org/10.2308/bria.2007.19.1.71

Fisher, J. (1995). Contingency-Based Research on Management Control Systems: Categorization by Level of Complexity. Journal of Accounting Literature, 14, 24-53. https://search. proquest.com/openview/b435f1b5566d2e 2 d412bbe1308958a38/1?pq-origsite $=$ gscholar\& $\mathrm{cbl}=31366$

Flamholtz, E. G., Das, T. K., \& Tsui, A. S. (1985). Toward An Integrative Framework of Organizational Control. Accounting, Organizations and Society, 10(1), 35-50. https://doi.org/https://doi.org/10.1016/03613682(85)90030-3

Govindarajan, V. (1986). Impact of Participation in the Budgetary Process on Managerial Attitudes and Performance: Universalistic and Contingency Perspectives. Decision Sciences, 17(4), 496-516. https://doi.org/10.1111/j.15405915.1986.tb00240.x 
Kaplan, S. E., Petersen, M. J., \& Samuels, J. A. (2012). An Examination of The Effect of Positive and Negative Performance on The Relative Weighting of Strategically and NonStrategically Linked Balanced Scorecard Measures. Behavioral Research in Accounting, 24(2), 133-151. https://doi.org/ $10.2308 /$ bria-50114

Kren, L. (1992). Budgetary Participation and Managerial Performance: The Impact of Information and Environmental Volatility. The Accounting Review, 67(3), 511-526. https:// doi.org/http://www.jstor.org/stable/247975

Kusuma, I. W. (2003). Akuntansi Keperilakuan dalam Jurnal Behavioral Research in Accounting (BRIA). Jurnal Bisnis Dan Akuntansi, 5(2), 147-166.https://doi.org/https://doi.org/10.34208/ jba.v5i2.560

Lau, C. M., \& Scully. G. (2015). The Roles of Organizational Politics and Fairness in the Relationship between Performance Management Systems and Trust. Behavioral Research in Accounting, 27(1), 25-53. https:/ /doi.org/https://doi.org/10.2308/bria-51055

Lee, C. M. C. (2001). Market Efficiency and Accounting Research: A Discussion of "Capital Market Research in Accounting" by S.P. Kothari. Journal of Accounting and Economics, 31(1-3), 233-253. https://doi.org/ 10.1016/S0165-4101(01)00038-6

Merchant, K., A., \& Van der Stede, W., A. (2007). Management Control Systems (2nd ed.). Harlow, Essex,. England: Prentice Hall, Pearson Education Limited.

Malmi, T., \& Brown, D. A. (2008). Management Control Systems as A Package-Opportunities, Challenges and Research Directions. Management Accounting Research, 19(4), 287-300.https://doi.org/10.1016/j.mar.2008. 09.003

Naranjo-Gil, D., Cuevas-Rodríguez, G., LópezCabrales, Á., \& Sánchez, J. M. (2012). The Effects of Incentive System and Cognitive Orientation on Teams' Performance. Behavioral Research in Accounting, 24(2), 177-191. https://doi.org/10.2308/bria-50098

Otley, D. (1999). Performance Management: A Framework for Management Control Systems
Research. Management Accounting Research, 10(4), 363-382. https://doi.org/10.1006/ mare. 1999.0115

Otley, D. (2016). The Contingency Theory of Management Accounting and Control: 19802014. Management Accounting Research, 31, 45-62. https://doi.org/10.1016/j.mar.2016.02.001

Riyanto, B. (2003). Model Kontijensi Sistem Pengendalian: Integrasi dan Ekstensi untuk Future Research. KOMPAK: Jurnal Akuntansi, Manajemen, dan Sistem Informasi, FE UTY Yogyakarta, April(9), 330-342.

Speklé, R. F; Elten, H. J van., \& Widener, S. K. (2017). Creativity and Control: A ParadoxEvidence from the Levers of Control Framework. Behavioral Research in Accounting, 29(2), 73-96. https://doi.org/https:/ /doi.org/10.2308/bria-51759

Rose, A. M., Rose, J. M., \& Norman, C. S. (2016). Material Control Weakness Corrections: The Enduring Effects of Trust in Management. Behavioral Research in Accounting, 28(2), 41-53. https://doi.org/https://doi.org/10.2308/ bria-51467

Sendjaja, W. (2015). Isu Terbaru di Dunia Akuntansi Manajemen. Akuntan Indonesia. AgustusSeptember 2015: 54-56.

SeTin, S. T., Agustina, L., \& Meyliana, M. (2017). A New Classification of Topics in Behavioral Accounting: Current Research Direction from BRIA Journal in The Past 10 Years. Journal of Business and Retail Management Research, 11(3), 47-58. https://jbrmr.com/cdn/ article_file/content_14094_17-04-23-13-0632.pdf

SeTin, S. T., \& MingKuang, T. (2010). Analisis Perkembangan Riset Akuntansi Keperilakuan Studi pada Jurnal Behavioral Research in Accounting (1998-2003). Jurnal Akuntansi, 2(2), 122-133. https://www.neliti.com/id/ publications/220077/analisis-perkembanganriset-akuntansi-keperilakuan-studi-pada-jurnalbehavioral

Tsamenyi, M., Sahadev, S., \& Qiao, Z. S. (2011). The Relationship Between Business Strategy, Management Control Systems and Performance: Evidence from China. Advances in Accounting, 
140 Jurnal Ilmiah Akuntansi dan Bisnis, Vol. 15, Issue. 1, January 2020

27(1), 193-203. https://doi.org/10.1016/ j.adiac.2011.05.001

Young, R. F. (2017). Blowing the Whistle: Individual Persuasion under Perceived Threat of Retaliation. Behavioral Research in Accounting, 29(2), 97-111. https://doi.org/ https://doi.org/10.2308/bria-51729
YuTian., Tuttle, B. M., \& YinXu. (2016). Using Incentives to Overcome The Negative Effects of Faultline Conflict on Individual Effort. Behavioral Research in Accounting, 28(1), 67-81. https://doi.org/https://doi.org/10.2308/ bria-51147 